Hanoch Ben-Pazi

\title{
Rebuilding the Feminine in Levinas's Talmudic Readings
}

"The female experience is other for the male experience, not only because of its different nature but because, in a certain sense, otherness is its nature". 1

This study presents a reconsideration of Levinas's concept of the feminine. This reconsideration facilitated by a philosophically informed analysis of Levinas's Talmudic readings on that subject.

The subjects of Levinas's exploration of the feminine, in this view, emerge from his Talmudic readings, but his phenomenological analysis of those very subjects goes beyond what can be found in those readings. Analyzing the meaning of the difference between the sexes - the topic of one of the Talmudic readings - leads Levinas to a wider phenomenological treatment of the status of woman that does not bypass the feminine voice. Delving into the Talmudic concept of rodef (persecutor) as applied to the relationship of fetus and mother leads Levinas to a phenomenological analysis of the concept of maternity and readiness to accept responsibility (even suffering) for the Other. Those two discussions lead us to a rereading of Levinas's essay "Phenomenology of Eros" and enable us to rebut the charge that in that essay Levinas presents only a masculine voice. Levinas's concept of "responsibility" will be seen to resemble the feminist psychologist Carol Gilligan's concept of "care." We must then reconsider whether Levinas's concept of the feminine is exclusively the domain of women.

\section{A Methodological Remark}

Among Levinas's philosophical writings, one may discern two types of works. One type is his strictly philosophical writings, in which he is an adherent of the phenomenological approach and has an important place in that school of thought. The second type is Levinas's "Talmudic readings," a genre unique to him in which he presents a philosophical reading of Talmudic passages in which the various opinions expressed and tested in the Talmud's treatment of an issue become part of our contemporary philosophical discourse.

\footnotetext{
${ }^{1}$ E. Levinas, Ethics and Infinity : Conversations With Philippe Nemo, trans.: R. Cohen, Pittsburgh 1991,
} p. 65. 
The starting point for my research is the assertion that Levinas's philosophical writings and his "Talmudic readings" are constituent parts of the same endeavor one that is essentially philosophical - and that, in keeping this assumption, one can wrest from the writings labeled "Talmudic readings" philosophical meanings that are not subjects of inquiry in his stringently philosophical writings.

Previous efforts to explore the significance of the feminine in Levinas's philosophy have focused, for the most part, on his philosophical writings. ${ }^{2}$ What I am attempting to accomplish here, then, is to demonstrate the contribution made by Levinas's "Talmudic readings" to his philosophical treatment of women and the feminine. ${ }^{3}$

\section{Sexual Difference}

Ethics, which Levinas bases upon a primary metaphysical imperative, rests upon the consciousness of the self and an awareness of the otherness of another human being. This otherness cannot be identified with what "resembles" it in the self. Therefore Levinas invests considerable energy in describing the phenomena in which the intrusion of the otherness of another human being into the self occurs. ${ }^{4}$

It appears that among Levinas's descriptions, one particular intrusion of consciousness stands out as undeniable: being addressed by the other gender - in Levinas's context as a man, the woman as Other. An encounter with a woman is the intrusion of an otherness that cannot be subsumed under or included by the male

2 Much has been written on the significance of the feminine in Levinas' philosophy. See, for example: R. A. Cohen, "the Metaphysics of Gender", Elevation: The Height of the Good in Rosenzweig and Levinas, Chicago and London 1994, pp. 195-219; L. Irigary, "Question to Emmanuel Levinas: On the Divinity of Love", Re-Reading Levinas, ed. R. Bernasconi and S. Critchley, Bloomington and Indianapolis 1991, pp. 109-118 ; C. Chalier, Figures du féminin, Paris 1982; C. Chalier, "Ethics and the Feminine", Re-Reading Levinas, pp. 119-129; T. Chanter, "Antigone's Dilemma” Re-Reading Levinas, pp. 130 - 146; T. Chanter, "Feminism and the Other", The Provocation of Levinas - Rethinking the Other, ed. R. Bernasconi and D. Wood, London and New York: 1988, pp. 32-56; R. Manning, "Thinking the Other Without Violence? An Analysis of the Relations Between the Philosophy of Emmanuel Levinas and Feminism", The Journal of Speculative Philosophy, 5:2 (1991), pp. 132-143 ; M.A. Ouaknin, Méditation érotiques - Essais sur Emmanuel Lévinas, Paris 1992; A. Ainley, "The Feminine, Otherness, Dwelling", Facing the Other: The Ethics of Emmanuel Levinas, ed. S. Hand, Richmond 1996, pp. 7-20; P. Kayser, Emmanuel Levinas: la trace du féminin, Paris: 2000 ; Levinas, Time Is the Breath of the Spirit - in conversation with B. Lichtenberg Etinger, trans.: J. Simas \& C. Ducker, Oxford 1993; In Hebrew:

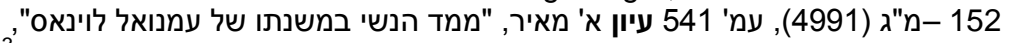

${ }^{3}$ In her recently published book, Levinas, Judaism, and the Feminine (Bloomington-Indianapolis 2003), Claire Elise Katz offers a similar approach to integrating Levinas's writings on Jewish themes into our understanding of his views of the feminine. While Katz focuses her attention on Levinas's treatment of Biblical narratives, with occasional reference to their exegesis in rabbinic midrash, this study explores Levinas's Talmudic readings, which are particularly rich in material that complements Levinas's more strictly philosophical work on our theme and others.

4 Levinas devotes a great deal of phenomenological writing to this topic, especially in his Totality and Infinity, transl. A. Lingis, Pittsburgh: 1969. See, for example: "Freedom Called into Question" (pp. 8284), "Separation as Life" (109-121), "Enjoyment and Separation" (147-151, "Sensibility and the Face" 
consciousness. From the male's perspective, she is clearly different. She is not him. This refers first of all to the more physical aspects of being, even before any attempt to identify unique characteristics of the feminine, if indeed these exist. An encounter of this sort is described in the writings of the French psychoanalyst Ida Feinberg and her Israeli colleague Yolanda Gampel as one of three narcissistic injuries experienced by every person. The fact that a person has a particular, identifiable gender, making that person a man or a woman but not both, strikes at the individual's primary narcissistic perception. ${ }^{5}$

Levinas identifies otherness of gender as an otherness that is not subject to Husserlian Reduction. On this point one can perceive a criticism of Husserl for not having approached woman with sufficient seriousness in his attempt to solve the problem of "experience of the other," the mode of presentation of the other as a different subject. That experience serves also as the test of the phenomenological reduction that Husserl performs ${ }^{6}$.

It would appear that, had Husserl taken the female subject seriously as a subject, the difference of gender would have overcome the attempt at reduction, and we would have found ourselves with an entire field or fields that Levinas labels "irreducible." The reason, according to Levinas, is that from the perspective of a man's concepts, woman is irreducible. She is the "absolute Other."

"What is the alterity that does not purely and simply enter into the opposition of two species of the same genus? I think the absolutely contrary contrary [le contraire contraire absolutement contraire], whose contrariety is in no way affected by the relationship that can be established between it and its correlative, the contrariety that permits its terms to remain absolutely other, is the feminine". ${ }^{8}$

The otherness of woman is the otherness that cannot be overcome. In this context, Levinas is attacking the view that speaks of the relations between a man and a woman as two complementary halves of a whole, since complementarity assumes a priori an identification of the other with the self and does not admit the possibility that the other may represent absolute otherness. Therefore it is important for him to point

5 The other two narcissitic injuries are: the fact that a person does not facilitate his own birth, and the fact that he is eventually going to pass over into death.

${ }^{6}$ E. Husserl, Cartesian Meditations, trans.: D. Cairns, The Hague, 1960, pp. $110-111$.

7 Of course, Levinas includes this thought, about the impossibility of reduction vis-à-vis any other individual, since an essential quality of otherness is that it cannot be reduced into the self's concepts of consciousness. Nonetheless, feminine otherness stands out inasmuch as gender difference does not make it possible for its bearer to identify with
${ }^{8}$ Levinas, Time and the Other, trans.: R. Cohen, Pittsburgh 1987, p. 85. 
out that this relation does not become a perfect whole but is an "insurmountable duality":

"Neither is the difference between the sexes the duality of two complementary terms, for two complementary terms presuppose a preexisting whole. To say that sexual duality presupposes a whole is to posit love beforehand as fusion. The pathos of love, however, consists in an insurmountable duality of beings. It is a relationship with what always slips away. The relationship does not ipso facto neutralize alterity but preserve it. The pathos of voluptuousness lies in the fact of being two. The other as other is not here an object that becomes ours or becomes us; to the contrary, it withdraws into its mystery. Neither does this mystery of the feminine - the feminine: essentially other - refer to any romantic notions of the mysterious, unknown, or misunderstood woman" 9

Two stances may be identified regarding the meaning of woman's otherness. The first speaks of woman's difference from man as an otherness that cannot be successfully grappled with by man. Woman, in her differentness, and first and foremost her sexual difference, puts man in a position that cannot be synthesized within the "identical" (le même). She is not similar to the male's concepts, and she forces him to come to grips with difference and otherness. In this sense, we could offer a similar description for woman of the differentness of man, whose sexual difference cannot be subsumed under the female concept of sexuality ${ }^{10}$.

The second stance, which will be developed below, ascribes an essential "otherness" to woman. The feminine includes within itself a dimension of "Other" or "Otherness." 11

The centrality of gender difference in Levinas's thought seems already to emerge from the very title of the "Talmudic reading" that Levinas dedicated to our topic: "And

\footnotetext{
${ }^{9}$ Time and the Other, p. 86

${ }^{10}$ P. Kayser, Emmanuel Lévinas: la trace du feminine, Paris 2000. Kayser's analysis of Levinas's concept of the differences between the sexes leads her to a critical stance toward what she sees as his use of the feminine as representation rather than as actual being. (See pp. 30-34.) 11 This term requires clarification, of course: what is that otherness ascribed by Levinas to woman, which is an essential otherness and not, as with man, something external? This issue will be clarified in the context of the discussion of the characteristics of the feminine according to Levinas, which is the main substance of this article.
} 
God Created Woman." ${ }^{12}$ This title appears to take issue with the view, apparently biblical, in which the male enjoys preferential status and priority, stemming from man's ontological primacy vis-à-vis woman. Levinas titles his article in such a way as to argue from the start that woman is an independent creation. Woman is not a creature derived from man, the product of his "deep sleep," and thus her status is not one of subjugation or secondariness relative to man but that of an independent product of Creation. This point of view is of great significance in the presentation of femininity and masculinity, of man and woman, as two creations ontologically different from one another:

"The creation of man was the creation of two beings in one but two beings equal in dignity: difference and sexual relations belong to the fundamental content of what is human"13.

Man and woman gain expression as distinct creatures, with neither taking precedence in time or status but with their difference from each other expressing a primary otherness. The gender difference is not a marginal distinction subsumed under the human, but rather a central component of the human phenomenon ${ }^{14}$.

The creation of woman separately from man underscores man's position in his inner world, which is not subject to generalization or to categorization. Woman is not something man understands from within himself; she is the absolute Other. And as such she is not subject to reduction.

\section{Man and Woman - Equality of Status}

One of the most important topics in feminist discourse is the dignity of women in society. Western culture established a stable distinction of status between men and women, facilitating discrimination. ${ }^{15}$ As Levinas said of Jewish culture:

\footnotetext{
12
}

Levinas, "And God Created Woman", Nine Talmudic Readings, trans.: A. Aaronovitz, Bloomington and Indianapolis: 1990, 161-177 ; the other Talmudic reading dedicated to this subject is "Judaism and the Feminine", Difficult Freedom, trans.: S. Hand, Baltimore 1990, pp. $30-38$

14 "Judaism and the Feminine," p. 34.

13 "And God Created Woman," p. 169.

${ }^{15}$ There is a wide feminist writings on this issue, so here will found only few important references: $\mathrm{E}$. Fisher, Woman's Creation: Sexual Evaluation and the Shaping of Society, New York 1979 ; S. B. Hardy, The Woman that Never Evolved, Cambridge 1981 ; Beyond Equality and Difference: Citizenship, 
"We are far from the conditions prevailing in the Orient where, at the heart of a masculine civilization, woman finds herself completely subordinate to masculine whims or reduced to charming or lightening the harsh life of men."16

Levinas places the question of women's equality as a secondary question to the principal one, that of the human duality. This position leads him to interpret the Talmudic phrase "God created two countenances in the first man" differently from the traditional commentaries.

Rashi for example interpreted the phrase:

"Two countenances - He made him at first with two faces, one in front and one in back, and split him in two and made Eve out of one," 17

For Levinas the problem of duality preceded the differentiation of two genders. This duality is not sexual at first but the human situation beyond gender. The duality is situated in the ability of humans to choose, in the sense of the human being as a creature endowed with knowledge. ${ }^{18}$ This duality is founded in the breach between natural impulses and moral imperatives. ${ }^{19}$ This is the duality between the outside - everything that calls a person to responsibility ${ }^{20}--$ and the inside.

The image of the double faces describes the interior duality of the human being. There is no possibility for the illusion of completeness of the person, because the division is primary. In Levinas's view, the Talmud treats the feminine and gender in keeping with its social ethics. The sexual differentiation is subordinate to the social differentiation, ${ }^{21}$

Feminist Politics and Female Subjectivity, ed. by G. Bock and S. James, New York 1992 ; Imaging Women: Cultural Representations and Gender, F. Bonner (ed.), Cambridge 1992 ; The Feminist Reader, C. Belsey \& J. Moore (eds.), New York 1989 ; M. French, Beyond Power: On Women, Men and Morals, New York 1985

16 "Judaism and the Feminine," p. 31.

${ }^{17}$ Rashi on Babylonian Talmud, Berakhot 61a.

18 "The Holy One, Blessed is $\mathrm{He}$, created man with two inclinations, one a good inclination and the other an evil inclination" (Babylonian Talmud, Berakhot 61a).

19 "Rabbi Shimon ben Pazi said: Woe to me from my Creator, and woe to me from my inclination" (idem, 61a). 
In the interpretation of the Tamudic passage, Levinas focuses on a dispute between the Babylonian sages Rav and Shmuel on the identification of the organ that God took to create Eve in Genesis ${ }^{22}$. This dispute deals with the question of women's status. For the Talmud there are two optional physical locations for this organ, the tail and the face:

\section{" 'And the tsela which the Lord had taken from man made he a woman' \\ -- Rav and Samuel explained this differently. One said that it was a face, the other said that it was a tail". ${ }^{23}$}

The interpretive instinct may lead the skilled reader to think that the tail expresses a diminished status for women. Levinas surprises us when he attributes greater gender equality to the opinion that sees this organ as a tail. He points out that the tail is not an essential part of the human body. Saying that Eve was created from the tail reduces the dependence of women on men. A new creation is necessary for the woman, just as it was for the man. Furthermore, perhaps the man is the first in the biblical story, but as long as there is no woman there is no meaning to his masculinity. When there is a meaning to gender, we can see that woman is God's creature just as man is. ${ }^{24}$

In this context it is possible to see the "tail" interpretation as a subordination of gender to the definition of a human being. To be a female is something additional to the humanness of the woman. She is a person and above that she has the additional characteristic of being a woman:
"They have other things to do besides cooing, and moreover, something else to do and more, than limit themselves to the relations that are established because of the differences in sex." 25

\footnotetext{
20 "R. Yirmiyah ben Elazar said: The Holy One Blessed is He, created two figures [or: faces] in the first man [Adam], as it says: [From the] back and the front You have formed me" (idem, 61a).

${ }^{21}$ The private problem is a political problem.

22 See Kayser's discussion of the term vayyitzer in Emmanuel Lévinas: la trace du feminine, pp. 52-59, 225-239. Her identification of difference as implying hierarchy is speculative, interpolating beyond Levinas's own statements. One might read Levinas as viewing the difference between the sexes as a non-hierarchical difference.

${ }^{23}$ Babylonian Talmud, Berakhot 61a.

${ }^{24}$ As was mentioned above, the title that Levinas gave to this Talmudic reading is related to this context

${ }^{25}$ Levinas, "And God Created Woman," p. 169. The reference to Freud is very clear, with the important emphasis to the limitation of sexuality in creating culture, even there is a price - guilt and guilt feelings.
} 
This explanation could have been accepted by Levinas. He prefers however to speak about sexual difference as a fundamental difference that is essential to what constructs the person as a person. A small remark of Levinas, one that may seem very naive, is significant in this context:

"As I see it, this is what my text shows. I am not taking sides, today, I am commenting" 26 .

Levinas chooses to describe the "tail" interpretation as a possible reading in the Talmud, which, although he disagrees with it, he could see as an important position. The reason is that this position is very important in feminist thought, when seeing the question of equality as the central topic of feminism. This may be Simone de Bouvoir's central point in her book, The Second Sex. ${ }^{27}$ In de Beauvoir's view, women are subordinated to men because of women's physical weakness as expressed in pregnancy. The only way to preserve social equality is by giving up pregnancy.

Levinas actually prefers the contrasting interpretation, that the organ was a face, which views the masculine and the feminine as primary characteristics.

Levinas's remark can be understood in this manner: this first position (tail) is legitimate and also has important advantages, but I, Levinas, do not prefer it. The reason is that the difference between men and women is essential.

A close reading of Levinas indicates that he prefers the interpretation according to which the woman is created from a face. In this reading, the first human being is shaped as two attached beings of equivalent status, but despite their equality they are two different beings. Gender, which is an expression of this difference, is not something that is subordinate to the definition

\footnotetext{
26 "And God Created Woman," p. 170.

${ }^{27}$ S. de Beauvoir, The Second Sex, trans.: H.M. Parshley, London 1960.
} 
of the human being but part of this definition. Sexuality is part of what defines a human being.

Rabbinical thought, according to Levinas, employs the Platonic myth about the ancient creature made of a man and a woman joined together. For Plato this is the origin of sexual attraction:

"For though 'hermaphrodite' is only used nowadays as a term of contempt, there really was a man-woman in those days, a being which was half male and half female. [...] Each of these beings was globular in shape, with rounded back and sides, four arms and four legs, and two faces, both the same $[\ldots]$

So saying, he cut them all in half just as you or I might chop up some apples for pickling, or slice an egg with hair. [...]

Now, when the work of bisection was complete it left each half with a desperate yearning for the other, and they ran together and flung their arms around each other's necks, and asked for nothing better than to be rolled into one. [...]

So you see, gentlemen, how far back we can trace our innate love for one another, and how this love is always trying to reintegrate our former nature, to make two into one, and to bridge the gulf between one human being and another"28.

The rabbinical position is markedly different. It sees the separate as preferable to the united. Difference is preferable to harmony. For the Rabbis this ancient creature was in internal conflict over the issue of which side would lead:

"Was this rib not a side of Adam, created as a single being with two faces that God separated while Adam, still androgynous, was sleeping? This theme perhaps evolved from Plato's Symposium, but it is one which in the Doctors takes on a new meaning. The two faces of the primitive Adam from the beginning look towards the side to which they

\footnotetext{
${ }^{28}$ Plato, Symposium, trans.: M. Joyce, The Collected Dialogues of Plato, E. Hemilton \& H. Cairns (eds.), Princeton 1989, pp. 542 - 544 [pp. $189-192]$.
} 
will always remain turned [...] For the Jews, separated existence will be worth more than the initial union"29.

\section{Equality as Ignoring the Feminine}

Levinas expresses concern that social equality comes at the price of denial of the feminine. While the position of equality seems more worthy both legally and publicly, for Levinas it is important first to state the importance of differentiation of gender, and only then to understand the place of the woman as a woman in the public space.

Levinas raises the problematic character of this position in a surprising context: the phenomenon of secularity and the de-mystification it entails. ${ }^{30}$ Levinas interprets a talmudic passage on the topic of sorcery. The Talmud questions the feminine language of the biblical verses in this topic: mekhashefot, witches. Is the Bible attributing sorcerers' powers particularly to women? Can one also find men who are involved in this kind of act?

Levinas wonders whether this language stems mainly from historical reasons, as some would claim: that is, the majority of sorcerers were women. According to this explanation this mode of speech expresses historical facts and not anything essential.

But Levinas argues against taking this text literally; there is something beyond it. The Talmud does not intend to draw a comparison between women and sorcerers, and then to suspect every woman of sorcery. Levinas supports this argument with the biblical descriptions of women such as Rebecca and Sarah. There are no verses that describe them as sorcerers.

Levinas focuses on the erotic dimension of the relationship between men and women. $\mathrm{He}$ notes the ambiguity related to the erotic phenomenon: the mystery, the revealed and the concealed. This ambiguity brings into the relationship between men and women a dimension of "forgery' that Levinas calls 'sorcery." It is not a concrete act, but the sexual seduction usually related to the feminine.

\footnotetext{
29 "Judaism and the Feminine," p. 35

${ }^{30}$ Désacralisation et désensorcellement," Du sacré au saint, Paris 1977, pp. 82 - 121, especially pp. 91 $-93$.
} 
Levinas next asks: why is it necessary to distinguish between masculine and feminine? This question applies to the Talmudic text, but we can turn it on Levinas himself. Is the feminine dimension possible when we only dealing with women's emancipation, women's freedom, and their entrance to the public space? Is the social sensitivity of not separating between men and women real emancipation? The fact that men formed the "general" dimension, that men created the meaning of the universal, led Levinas to ask this question: Can we talk about equal status when women join in the masculine context? Or is it possible to talk about equality only when women enter the public space as women?

\section{Characteristics of the Feminine}

The significance of the argument that the distinction of gender between man and woman is primary is that of necessity it raises the question: what is the meaning of this distinction?

In his strictly philosophical writing, Levinas characterizes the feminine in several ways: the feminine as connected to the dimension of future time; a different direction of the motion of transcendence, directed inward; the characteristic of domesticity; the phenomenon of pregnancy and maternity; the phenomenon of the erotic. In his Talmudic writing, Levinas focuses on only two characteristics that are the starting point for thinking about the feminine: first, that of pregnancy and its ethical and philosophical concomitants and, second, the phenomenon of eros and its ethical concomitants.

These two phenomena are raised by Levinas in his Talmudic reading, "And God Created Woman", ${ }^{31}$ as two uniquely feminine characteristics related to the midrash on the word vayyiven in Genesis 2:22: "And the Lord God fashioned the rib that He had taken from the man into a woman....". The Talmud offers two characterizations of this feminine

\footnotetext{
31 “And God Created Woman," p. 174
} 
construction. One characterization, that of beautification, is explained by Levinas as a quality related to the erotic realm of male-female interaction. The second, central in Levinas's view, is that of pregnancy, being a home to a gestating being. These two qualities are fundamental and basic in Levinas's philosophy, and therefore they are the basis for the other qualities.

The Talmudic description of beauty is interpreted by Levinas as Eros. To the direct and honest relationship between men and women, sexual difference adds attention to external appearance. Thus the deep meaning of beauty includes a measure of "forgery." Taking responsibility for this sexual difference is problematic because one approaches the female other not only as an other but also as a woman. One does not relate directly to the other person exposed before him. ${ }^{32}$ One relates to the other through the other's mask, or the other's Persona.

Levinas raises this issue again, when the Talmud explains that it is not simple for a man to walk after a woman. Levinas' interpretation is that the meeting between man and woman is not simply "one and the other"; it is fraught with ambiguity. This meeting includes the erotic side, and communication between them includes the sweetness of intimacy. As if the relation became "soiled" because of the "forgery." Levinas expresses suspicion of the sweetness, of the temptation of tenderness.

The second quality of the feminine in the Talmud is biological and belongs only to woman: pregnancy. Discussion of pregnancy has been part of feminist theories for a long time, arising from de Beauvoir's position. Pregnancy limits the "being" of women as human beings, because it limits them to the role of mother.

Levinas develops a philosophical observation of the phenomenon of pregnancy. He tries to derive from this phenomenon the meaning of motherhood and a new meaning of subjectivity. 


\section{Pregnancy and its Ethical Implications}

"Another explanation: Rav Hisda said - and others said that it was taught in a baraita: The Torah teaches us that the Holy One, blessed be $\mathrm{He}$, made Eve like a granary. For just as the granary is narrow at the top and large at the bottom to hold the harvest, so woman is narrow at the top and large at the bottom to hold the child, ${ }^{, 33}$

Maimonides refers to pregnancy when trying to illustrate the impossible mission of understanding creation. He suggests imagining an orphan growing up on a deserted island, that in one way or another finds out the facts of pregnancy, the fact of there being a person within another person:

"Now the orphaned child must of necessity put the question: Did every individual among us - when he was little, contained within a belly, but alive and moving and growing - did he eat, drink, breathe through the mouth and nose, produce excrements? [...] Similarly all the analogies will be carried on in order to show that it is in no respect possible that man should be generated in that manner." 34 .

Pregnancy is a situation in which a person contains the other within herself, at once both a part of her and entirely separate from her. The body's usual response is to reject a foreign body that has made its way inside it, but not in the case of pregnancy, which protects and sustains the stranger within.

Husserl, in the "Fifth Meditation" of his Cartesian Meditations, investigates the possibility of identifying a living body outside oneself as another person by means of the physical senses.

\footnotetext{
${ }^{32}$ The exposure of the face with its nakedness and its revealing is very central in Levinas's philosophy. Levinas sees the face as a non-phenomenal phenomenon that establishes the ethics from the other's face. See Levinas, Totality and Infinity, pp. 187 - 219.

${ }^{33}$ Babylonian Talmud, Berakhot 61a.

${ }^{34}$ Moses Maimonides, The Guide of the Perplexed, trans.: S. Pines, Chicago and London 1963, II:17, pp. 295-296.
} 
The I establishes its consciousness of its own body on the basis of its awareness of its own ability to integrate the various senses and make one's own perceived body into an object. But the body of the other is always there as an object, and thus I cannot perceive that it is a living body other through the imagination, which enables me to think that the object that presents itself to me as a body is similar to me and is thus also alive:

"In this Nature and in this world, my animate organism (a function organ), the body over there, which is nevertheless apprehended as an animate organism, must have derived this sense by an apperceptive transfer from my animate organism, and done so in a manner that excludes an actually direct, and hence primordial, showing of the predicates belonging to an animate organism specifically, a showing of them in perception proper. It is clear from the very beginning that only a similarity connecting, within my primordial sphere, that body over there with my body can serve as the motivational basis for the "analogizing" apprehension of that body as another animate organism"35.

If Husserl had given consideration to the woman as subject and to the phenomenon of pregnancy, he could have found the situation of accepting the other within one's body and perforce responsibility as well for that one that is other than oneself. Levinas describes things that way - pregnancy as a state of being pursued by someone for whom you are responsible. That pained sigh, those inner sufferings that express absolute responsibility toward something that is other than you - this is a distinctly ethical characteristic that passes beyond itself, from pregnancy into the concept of maternity. The source of the image Levinas employs, "being responsible for one by whom you are being pursued," is the talmudic discussion of the response to someone pursuing another person with harmful intent. Situations may occur in which the fetus proves harmful to the health or survival of the mother.

${ }^{35}$ E. Husserl, Cartesian Meditations, trans.: D. Cairns, The Hague, 1960, pp. 110 - 111. 
In his book Otherwise than Being or Beyond Essence, Levinas develops the image of pregnancy as something that breaks out of every framework of consciousness, precisely when we consider maternity as a physical, bodily experience. The thought of maternity destroys the possibility of talking about relations only in an external fashion, since with pregnancy, the meaning of the concept is embodied. Sensitivity does not begin with awareness of the other, but within the body. This sensitivity includes being pursued in a very real fashion by a stranger, but maternity contains the paradox of wanting this being-pursued and even being responsible for this pursuit. This is the sigh that encompasses pregnancy, which is the result of being pursued by the one who is to be born or has been born.

It should be emphasized that from Levinas's perspective, maternity is not just the phenomenon of pregnancy; it is subject to expansion into thinking about relations with an other that are not preceded by the consciousness of a subject:

"It is a pre-original not resting on oneself, the restlessness of someone persecuted - Where to be? How to be? It is a writhing in the tight dimension of pain, the unsuspected dimension of the rejection into the negative, behind nothingness; it is maternity, gestation of the other in the same. Is not the restlessness of someone persecuted but a modification of maternity, the groaning of the wounded entrails by those it will bear or has borne? In maternity what signifies is a responsibility for others, to the point of substitution for others and suffering both from the effect of persecution itself in which the persecutor sinks. Maternity, which is bearing par excellence, bears even the responsibility for the persecuting by the persecutor"36.

The circles of maternal responsibility are deep, because they contain an irrevocable responsibility for and to the person who is one's difficulty ${ }^{37}$.

\footnotetext{
${ }^{36}$ Otherwise than Being or Beyond Essence, p. 75.

${ }^{37}$ See Kayser's discussion of maternity in Emmanuel Lévinas: la trace du feminine, pp. 96-109. Her emphasis is on "l'Autre dans le-Même."

On the concept of "dwelling," see Katz, Levinas, Judaism, and the Feminine, pp. 56-61. Katz's own use of the term "dwelling" in her fascinating and enlightening treatment of the Book of Ruth (pp. 89-96) sets into sharp relief that book's attitude regarding the ethics of relations with strangers. See also Claire Elise Katz, "Reinhabiting the House of Ruth: Exceeding the Limits of the Feminine in Levinas," Feminist
} 
But this is not enough for Levinas, since maternity is not just this guarantee but a reminder of the "immemorial memory" of the self. Levinas appears here to touch upon the I's difficulty with assuming itself as a certainty and as a basis for consciousness, with pregnancy being a reminder to the individual of his or her own having once been born. Whoever is born cannot be a source of certainty or of primacy. A born being is not a basis for full consciousness or one who establishes a world.

"Maternity is the complete being 'for the other' which characterized it, which is the very signifyingness of signification, is the ultimate sense of this vulnerability. This hither side of identity is not reducible to the foritself. Where, beyond its immediate identity, being recognizes itself in its difference," 38

Maternity, then, is a surprising, fascinating phenomenon that takes in all the necessary dimensions of being for an Other. It attains significance by making a meaning other than itself possible. It receives its identity not by virtue of being for itself but by virtue of being for another.

The centrality of the phenomenon of a woman's pregnancy is noted within feminist thought as well, as a major point of contention. There have been those who view pregnancy as a crisis and the choice of maternity as a woman's becoming weaker and more vulnerable, dependent upon a man and thus having a lower social status. Therefore, in Simone de Beauvoir's suggestion, ${ }^{39}$ each woman has the choice of opting either for maternity or for human equality. One is not born a woman; one becomes a woman.

Interpretations of Emmanuel Levinas, Tina Chanter (ed.), University Park, Pennsylvania 2001, pp. 145170.

${ }^{38}$ Otherwise than Being or Beyond Essence, p. 108.

${ }^{39} \mathrm{~S}$. de Beauvoir, The Second Sex. 
In a more refined fashion, we can discern a similar description of maternity in the writing of Sara Ruddick..$^{40}$ In her view, the practicalities of maternity direct the mother into relinquishing part of her power for the benefit of her children. Maternal thinking ${ }^{41}$ is unique by virtue of its being a consciousness directed toward the other and relating to others as free subjects. ${ }^{42}$ Ruddick - and there is a certain parallel with Levinas - thus calls for integrating the maternal voice into political discourse. Maternal thinking in public discourse would include a pacifist dimension, protecting life, and would stand opposite male thinking, which is based on militarism and destruction and is therefore an element of death.

In another place, ${ }^{43}$ Levinas directs the reader to the connection between thought about God and pregnancy, between God and the womb. In rabbinic parlance, God is sometimes called Rakhmana, "The Merciful One," derived from the Aramaic term for "love," whose root letters (r-h-m) are the same as those the Hebrew term for "womb," rekhem. That divine epithet, then, can be seen to derive from relating to God as a uterus.

"Rakhamim is the relation of the other, whose gestation takes place within it. Rakhamim is maternity itself." ${ }^{44}$

The idea of divinity as womb is one that makes it possible to describe God's infinite nature as an openness to different possibilities, an openness to a future time that will arrive by human agency. The womb as the possibility of containment, the ability of opening up to the other, is a distinctly feminine phenomenon.

\footnotetext{
${ }^{40}$ S. Ruddick, Maternal Thinking: Toward a Politics of Peace, Boston 1980.

${ }^{41}$ Ruddick, Maternal Thinking; T. Bowers, The Politics of Motherhood, Cambridge 1996; N. J. Chodrow, The Reproduction of Mothering, Berkeley 1978; Mothering, J. Treblicot (ed.), Maryland 1983.

${ }^{42}$ Ruddick also describes the danger of maternal thinking, which makes for great power in the private realm along with low feminine social status and its concomitant, powerlessness in the public sphere. That can make female maternity into bossiness and arrogance, in an attempt to include a public dimension within the private sphere.

43 "Damages Due to Fire," Nine Talmudic Readings, pp. 178-197.

44 "Damages Due to Fire," p. 183.
} 
"God as merciful is God defined by maternity. A feminine element is stirred in the depth of this mercy. This maternal element in divine paternity is very remarkable." ${ }^{\prime 45}$

Levinas sees pregnancy as something that sets the feminine apart as unique. Furthermore, the phenomenon of pregnancy has social significance and moral implications. Not only must there be recognition of the importance of the private sphere as private, as it is expressed in pregnancy and childbirth, but pregnancy as a phenomenon has social and moral implications.

From an examination of the phenomenon of pregnancy Levinas wants to infer the concept of maternity, and from it the concept of fatherhood and of parenthood in general, as a key concept for understanding responsibility toward the other, even at the price of having the other do something injurious to oneself. This is a form of welcoming, of hospitality, in his words, that goes beyond the limits of alienated encounter.

\section{Maternity and the Meaning of Dwelling}

A concept derived from the phenomenon of pregnancy is that of domesticity, which constitutes a development of thought about pregnancy. Levinas grants thought about "dwelling" a separate place and a distinguished status.

In his book Totality and Infinity, Levinas discusses the concept of dwelling. In the philosophical context, it appears that this part of the discussion is directed polemically at Heidegger. The source of the discussion of domesticity, though, is not in Freudian "angst" or Heideggerian "thrownness" [geworfen]: "he does not find himself brutally cast forth and forsaken in the world." ${ }^{47}$ The source is in the Talmudic context, where we find this:

\footnotetext{
45 "Damages Due to Fire," p. 183

${ }^{46}$ Freud described horror with German term Unheimlichkeit - the Uncanny in the sense of something not natural or not in its natural place or home. See S. Freud, "The Uncanny" (1919), trans.: A. Strachely, Studies in Parapsychology, P. Rieff (ed.), New York 1963, pp. 19 - 62.

47 "Totality and Infinity," p. 152.
} 
"[...] In a world that offers it no inner refuge, in which it is disorientated, solitary and wandering $[\ldots]$ "The house is woman" the Talmud tells us." 48

This relating of woman to the home occurs many times in the Talmud. ${ }^{49}$ In Talmudic Aramaic, we find the term debitu for "woman," a term that may connect woman to the home (Hebrew bayit), because it can be interpreted as "[the one] located in the house." ${ }^{50}$ In Levinas's parlance, the term "home" or domesticity goes beyond the descriptive social usage of the term, extending it even to the meaning of "being in the world."

Characterizing woman as "home" may sound derisive, viewing the woman as home to the man, who goes out into the world. The passage about the ideal wife in Proverbs 31 can be understood this way, with the woman providing assistance and support for her man. The dual term for Eve as Adam's "help meet for him" ('ezer ke-negdo) in Genesis 2 also lends itself to such an image.

Levinas's concept of woman as home, though, runs deeper than that and indeed stands in contrast to Heidegger. Heidegger describes the situation of the Dasein's being as "thrown into the world." Authenticity lies in accepting the facticity of this fact. Levinas uses a difficult metaphor to describe this facticity, that of an actual projectile, a "stone one casts behind oneself." ${ }^{51}$ Opposite the possibility of projectedness is "home-ness/dwelling."

One possible perception of "home" would describe it as a person's protected space, a deliberate turning away from the external and a gathering inward into one's interior. Levinas considers this a male perception. There is another possibility for understanding "home," one that Levinas identifies with the feminine. This is home not as shelter but as "dwelling," a

\footnotetext{
48 "Judaism and the Feminine," pp. $31-33$.

${ }^{49}$ See, for example, Babylonian Talmud, Yoma 2a: "ביתו זו אשתו".

${ }^{50}$ For the frequent use of the term in the Talmud, see for example Berakhot 10a and Shabbat 23b. On the interpretation of debitu, see, for example, Babylonian Talmud, Ketubot 67b.

51 Totality and Infinity, p. 156.
} 
home that is domesticity intended to welcome, one that remains open in order to accept guests. The male world is alienated, says Levinas, industrial fabrication offers progress and technology - of an alienated sort. Woman offers an alternative in an alienated world, an alternative called "home." We know the phrase "to feel at home." Its meaning is not to "to feel protected" but rather to feel that one is moving inward to a familiar place, a welcoming place. It is a motion of transition - not an outward one, though, but an inward one. ${ }^{52}$

Levinas cites in this context two Talmudic descriptions. One delicately describes, in a somewhat fanciful reading of the verses in Genesis preceding the creation of Eve, how Adam "copulated [or: attempted to copulate] with every wild animal and beast." Looking for a sexual partner, Adam first tried out all the animals, but he knew he had not found the right partner until he met Eve. An odd and vulgar story, it would seem. Levinas takes it to mean that woman is not an answer to a need, woman is not a sexual response to man's needs. At that level, man resembles every other animal, and at that level he can find his sexual fulfillment, or a response to his sexual needs, his need for sexual pleasure, even without being dependent on a woman. What woman offers man is something not sexual, or beyond sexuality - dwelling, motion in another direction. Levinas is looking to describe as vividly as possible, although in modest language, the vagina as home. But this home is welcoming, it turns an outward movement into an inward movement. It makes a movement of alienation into a movement of intimacy. Woman not only solves the mythical Adam's problem of loneliness but she grants him "peace" in the sense of undoing his sense of alienation from the world.

The second Talmudic description continues the discussion with another midrash embellishing a biblical story. Rabbi Yose met the prophet Elijah and took that opportunity to ask him the meaning of the biblical phrase mentioned above, 'ezer ke-negdo (literally, "a help opposite him”). Elijah's answer is roughly this: man brings home wheat, but can he eat wheat? A man

\footnotetext{
${ }^{52} \mathrm{~V}$. Bion describes home as a container that collects the various aspects of one's personality.
} 
brings home flax, but can he wear flax? Woman turns the flax into clothing and the wheat into bread.

Levinas examines the two characteristics that the Rabbis ascribe to woman through Elijah. Wheat and flax are tools that man produces. He has separated from nature, overcome nature, and learned to produce in agriculture. What is odd about Elijah's answer is the need for woman to process the wheat into bread. Wouldn't a mere helper, or to put it bluntly, a servant, have been sufficient? Rather, says Levinas, the meaning of Elijah's response is in the reversal of movement. If the male's movement is the conquest of nature for the sake of his needs, the female offers the opposite movement, homeward, of the clothing and the bread. Making wheat into bread is certainly one of the symbols of domestic sensibility.

Male civilization is a civilization of conquest, if not of a common enemy then of nature. Female civilization is a civilization of humaneness, of domesticity, of "peace," a civilization of ethics. In the terms Levinas uses in this context, borrowed from the Talmud, feminine civilization grants "blessing" and "joy" and gives "light." 53

"To light eyes that are blind, to restore to equilibrium, and so to overcome an alienation which ultimately results from the very virility of the universal and all-conquering logos that stalks the very shadows that could have sheltered it, should be the ontological function of the feminine" 54 .

From Levinas's perspective, this topic already instructs us about the connection, which will become very significant in Levinas's thought, between the feminine and the future.

In his book, Time and the Other, Levinas grapples with the meaning of future time. ${ }^{55}$ For him, the future will be an entry of that which is beyond time into the present in such a way as to

\footnotetext{
53 "Judaism and the Feminine," pp. 32-33. The topic of light will be taken up below.

54 Judaism and the Feminine, p. 33

55 Time and the Other, pp. $71-74,90-94$
} 
command in him responsibility that is open to the other. This is the nature of messianic consciousness for him, but the feminine dimension is such as well.

The future exists within the feminine itself as that which does not attempt to conquer in an outward direction. It makes coming events possible, the future that does not seek to become the present but instead one that has not yet arrived. The actual expression of this is the manner of greeting, of welcoming guests, described above, which makes it possible to accept anyone who comes and does not know who might arrive or when. ${ }^{56}$

To put it in different terms, what is described by Levinas is the messianic future, the one that will come without my knowing when, the one that comes to me from another person and commands me to accept a moral mission directed toward the future.

\section{The Phenomenon of Eros}

The phenomenon of Eros is not unconnected to the phenomenon of pregnancy, but it nevertheless extends beyond it, not in an inward motion but in outward motion. The erotic realm brings us before two additional characteristics of the feminine, in Levinas's view: "future time" and a different direction of movement of transcendence.

The dimension of future time exists within the feminine in the way that erotic tension exists between a man and a woman. Eros is always a thing of the future, not only in that it makes childbirth possible, being the existence of what does not yet exist in the available present, but also in that in eroticism something always slips away from us, always eludes our perception. Thus Levinas prefers to describe the erotic by the phenomenon of the caress:

"The caress is a mode of the subject's being, where the subject who is in contact with another goes beyond this contact. Contact as sensation is part of the world of light. But what is caressed is not touched, properly

${ }^{56}$ Totality and Infinity, pp.155 - 156 ; Levinas, "Messianic Texts", Difficult Freedom, pp. 59 - 96 ; 
speaking. It is not the softness or warmth of the hand given in contact that the caress seeks. The seeking of the caress constitutes its essence by the fact that the caress does not know what it seeks. This "not knowing," this fundamental disorder, is the essential. It is like a game with something slipping away, a game absolutely without project or plan, not with what can become ours or us, but with something other, always other, always inaccessible, and always still to come [à venir]. The caress is the anticipation of this pure future [avenir], without content. It is made up of this increase of hunger, of ever richer promises, opening new perspectives onto the ungraspable. It feeds on countless hungers" ${ }^{\prime 5}$.

Like the feminine itself, so messianism is anticipation, hope for a future not yet arrived, unknown, that opens up possibilities but does not make them into "being." It is always future, always not yet. Anticipation and openness to the possible are part of both the feminine and the messianic. The intrusion of the future into the present as an as-yet-unrealized, unknown future is essential to the phenomenon of the feminine in Levinas. Thus the feminine becomes the motive force of messianism, not as that which is hidden within the available present but as that which is not present there.

"Woman is the category of future, the ecstasy of future. It is that human possibility which consists in saying that the life of another human being is more important than my own, that the Other comes before me, that the value of the Other is asserted before my own.

In the future, there is what might happen to me. And there is also my death." ${ }^{" 58}$

Levinas connects woman, future, and messianism under the metaphor of changes along "the messianic train on the actual path of sacred history." ${ }^{, 59}$ The train of messianic history would be in danger, as it were, of jumping the track, were it not for feminine supervision and alertness.

${ }^{57}$ Time and the Other, p. 89.

${ }^{58}$ Levinas in conversation with Beracha Lichtenberg Ettinger, B. Lichtenberg-Ettinger, Time is the Breath of the Spirit, trans.: J. Simas and C. Ducker, Oxford 1993. 
The description of the messianic train of history implies determinism, with the tracks determining the path it takes. But such a determinism is the very opposite of messianism, and thus the ones who can rescue messianism are women, or femininity. It is femininity that is able to face a future that does not arrive and extract the present from being forever "stuck" in the existing situation. This may be the deeper meaning if the expression "sacred history" for Levinas. ${ }^{60}$

Whithout spelling out his intent, Levinas directs our attention to the biblical Miriam, who brings a wetnurse for her brother Moses, and according to midrashic legends, it is Miriam who brought about the birth of Moses, the instrument of redemption.$^{61} \mathrm{He}$ also directs our attention to Tamar, who made it possible for Peretz and Zerach to be born and thus, down the line, King David. ${ }^{62}$ These situations and others described in the Torah are always at the edge of the visible. ${ }^{63}$ This is no accident, says Levinas, since the feminine is at the edge of the visible. The feminine is not the revealed world but precisely the inner world that is not present, and this gives rise to its openness to the future, to what is yet to come. It is precisely the ability to sustain a domain that is not public that makes it possible to effect change in the public domain - what we call "history." Openess to the other can redirect history and thus convert it into "sacred history."

The encounter with the masculine concept of the future, as described by Levinas, may take place in the present, in the form of suspicion toward the other person who approaches me. ${ }^{64}$

\footnotetext{
59 "Judaism and the Feminine," p. 31.

${ }^{60}$ The term used by Levinas here, "Sacred History," is problematic because of the usual use of this term in the religious context, especially in Christian sense, and see also C. Chalier, "L'histoire sainte," Emmanuel Lévinas et l'histoire, N. Frogneux \& F. Mies (eds.), Paris 1998, pp. 235-257 .

${ }^{61}$ Shemot Rabba A 19, 21.

62 See Bereshit Rabba 81.

${ }^{63}$ Both Rebecca and Tamar act behind the scenes.

${ }^{64}$ Levinas asks about this idea and the menace of the death in a different mode from the Heideggerian reflection on death. See Sein zum Tode in the context of Heidegger: M. Heidegger, Being and Time, pp. 216-246, and Levinas "Observation" in Totality and Infinity, pp. 197-201, 232-240.
} 
The feminine concept of the future can be optimistic, since it is open to the possibility of a future that will become present, in the same way as an absence may become a presence.

\section{The Ambiguity of the Erotic}

One can go beyond the Talmudic understanding of the erotic phenomenon, as Levinas did in 'Phenomenology of Eros." ${ }^{95}$ The erotic is directed from the one to the other, not as a mode of revealing the other but as a mode of relationship with something secret. The erotic always is always directed toward "not yet," so it is always hidden:

"The essentially hidden thrown itself toward the light, without becoming signification. Not nothingness - but what is not yet." 66

"'Being not yet' is not a this or a that; clandestinity exhausts the essence of this non-essence." 67

Eroticism is a phenomenon that is defined not by its essence, but by its non-essence. One cannot understand the phenomenon of eroticism if he does not realize it is ambiguous. The erotic event is simultaneously secrecy and exposure, modesty and licentiousness, presentness and absence of nudity. Levinas calls this ambiguity "femininity:"

"The simultaneity or the equivocation of this fragility and this weight of non-signifyingness [non-significance], heavier than the weight of the formless real, we shall term femininity." 68

The erotic is not a biological or physiological event, and it is not the "face" that someone meets. As previously mentioned, the complete expression of eroticism is the caress. The caress is not a clear body gesture, but always "not yet" - directed to the future. The occurrence of the erotic event is not revealing the hidden, but precisely the revealing of being hidden.

\footnotetext{
${ }^{65}$ Totality and Infinity, pp. 256-267.

66 idem, p. 256.

67 idem, p. 257.
} 
"Voluptuosity [...] discovers the hidden as hidden." 69

Contrary to popular descriptions, the actualization of the erotic does not in any way mean exposing. Hiding is not revealed, night is not illuminated, mystery is not removed:

"To discover here means to violate, rather than to disclose a secret [...]. The erotic nudity says the inexpressible, but the inexpressible is not separable from a clear speech that seeks to circumscribe it [...]

In this sense voluptuosity is a pure experience, an experience which does not pass into any concept, which remains blindly experience. Profanation, the revelation of the hidden as hidden, constitutes a model of being irreducible to intentionality, which is objectifying even in praxis, for not taking leave of 'numbers and beings." "’70

Levinas describes this dimension of the hidden as separate from words or emptied of words.

The beloved becomes embodied, in a way that exposes it to "being," to the il-y-a:

"The beloved, returned to the stage of infancy without responsibility this coquettish head, this youth, this pure life "a bit silly" - has quit her status as a person. The face fades, and in its impersonal and inexpressive neutrality is prolonged, in ambiguity, into animality. The relations with the Other are enacted in play; one plays with the Other as with a young animal." 71

Levinas has been criticized harshly for his metaphor in this paragraph ${ }^{72}$. The criticism focuses on the passive role that he relates to the woman:

\footnotetext{
68 idem, p. 257.

69 idem, p. 260.

70 idem, pp. 260-261.

${ }^{71}$ idem, p. 263.

${ }^{72}$ See Lucy Iragary's trenchant feminist critique of Levinas's understanding of the feminine: L. Iragary, "The Fecundity of the Caress: A Reading of Levinas, Totality and Infininity, 'Phenomenology of Eros," Feminist Interpretations of Emmanuel Levinas, pp. 119-144. See also Claire Elise Katz's response in Chapter 5 of Levinas, Judaism, and the Feminine.

The manner in which feminists have responded to Levinas's analysis of the feminine is discussed in D. Perpich, "From the Caress to the Word," Feminist Interpretations of Emmanuel Levinas, pp. 28-52. Perpich discerns two stages in Levinas's approach, two different modes of interpretation stemming from a development in Levinas's understanding of the concept of transcendence: from transcendent existence to transcendent ethics, which is beyond existence. Despite the progress in his thinking, Perpich sees Levinas's approach as unacceptable to feminists because of his sexist language.
} 
"This description of pleasure given by Levinas is unacceptable to the extent that it presents man as the sole subject exercising his desire and his appetite upon the woman who is deprived of subjectivity except to seduce him... In my opinion, if there us a fall, it is located in the reduction of the feminine to the passive, to the past tense, and to the object of man's pleasure, in the identification of the woman with the beloved."

It is important to remark on the beastly dimension of which Levinas speaks - not as a relation to another subject but as an erotic relation. The erotic connection empties words, because one waives the option of revealing in favor of leaving the hidden hidden. Exposure, in the sense of nudity, does not expose the Other before oneself.

The erotic proceeds beyond the face. We are not dealing here with the face as a mask, but with "the face of the face:"

"The hidden - never hidden enough - is beyond the personal and as its reverse, refractory to the light, a category exterior to the play of being and nothingness, beyond the possible, for absolutely ungraspable. Its way beyond the possible is manifested in the non-sociality of the society of lovers, their refusal to give themselves over in the midst of their abandon, this refusal to surrender themselves that constitutes voluptuosity, fed by its own hungers, approaching, in vertigo, the hidden $r$ the feminine, a non-personal, but into which the personal will not be engulfed." 74

\section{Is the Feminine in Levinas's Thought Exclusive to Women?}

Donna Brody, too, points out the shift in Levinas's point of view regarding the feminine. In her view, Levinas moves from masculine speech about the concepts of "woman" and "child" to feminine speech focused on a description of motherhood. See D. Brody, "Levinas's Maternal Method from 'Time and Other' Through Otherwise Than Being: No Woman's Land?” Feminist Interpretations of Emmanuel Levinas, pp. 53-77.

${ }^{73}$ L. Irigaray, "Questions to Emmanuel Levinas: On the Divinity of Love", Re-Reading Levinas, R. Bernasconi \& S. Critchley (eds.), Bloomington - Indinapolis 1991, p. 115.

${ }^{74}$ Totality and Infinity, p. 264. 
At this point, a question arises to which it is difficult to find an definitive answer in Levinas's works: does his outlook permit feminine thinking to be found among men, or among people simply as people? More radically, we might ask: does Levinas's thought in some way constitute a form of feminine thought? In her book Figures $d u$ feminine, Catherine Chalier questions whether Levinas addresses woman as a metaphor or as a real person. ${ }^{75}$

Is it possible to view Levinas's phenomenology of the feminine as an example - even a central example -- of his ethical thinking? May we regard his description of the feminine as itself feminine thought?

A fascinating parallel to Levinas in this respect can be found in the work of Carol Gilligan as reflected in her book, In a Different Voice. ${ }^{76}$ This parallel between their positions may assist us in answering our question.

Gilligan describes two modes of moral reasoning, one masculine and one feminine. Masculine morality is based on consciousness of the self and of the rights of the individual. It forms the foundation of the ability to make ethical decisions that are the result of a confrontation between different wills, different rights. It resembles the scale proposed by Lawrence Kohlberg. Feminine morality, on the other hand, is based on empathy, concern, and responsibility toward others.

Feminine moral reasoning is different. In Gilligan's words:

"The morality of rights differs from the morality of responsibility in its emphasis on separation rather than connection, in its consideration of the individual rather than the relationship as primacy."${ }^{977}$

\footnotetext{
${ }^{75}$ C. Chalier, Figures du féminin, Paris 1982, p. 62.

${ }^{76}$ C. Gilligan, In a Different Voice: Psychological Theory and Women's Development, Cambridge, Massachusetts and London, 1982. For critiques of Gilligan, see : J. Auerbach, L. Blum, U, Smith, C. Williams, "Commentary on Gilligan's In a Different Voice", Feminist Studies 11 (1985), pp. 149 - 162 ; D. Puka, "The Liberation of Caring: A Different Voice for Gilligan's Different Voice", Hypatia 55 (1999), pp. $58-82$.

C. Gilligan, "In A Different Voice: Women's Conceptions of Self and Morality," Harvard Educational Review 47 (1977), pp. 481-517.
} 
Levinas describes the otherness of femininity in a similar fashion, as something unlike the masculine attitude toward otherness. Masculine otherness is always external, outside the person. It is externality, and yet:

"[...] This feminine alterity does not consist in the object's simple exteriority. Neither is it made up of an opposition of wills." ${ }^{\text {78 }}$

The different mode of decision-making is based on her observations of differences between men and women in the perception of human relations:

"Consequently, relationship, and particularly issues of dependency, are experienced differently by women and men. For boys and men, separation and individuation are critically tied to gender identity since separation from the mother is essential for the development of masculinity. For girls and women, issues of femininity or feminine identity do not depend on the achievement of separation from the mother or on the progress of individuation. Since masculinity is defined through separation while femininity is defined through attachment, male gender identity is threatened by intimacy while female gender identity is threatened by separation." 79

As we recall, Levinas describes the phenomenon of the erotic thus:

"The relationship does not ipso facto neutralize alterity but preserve it... The other as other is not here an object that becomes ours or becomes us; to the contrary, it withdraws into its mystery."

"It is a relationship with alterity, with mystery - that is to say, with the future, with what (in a world where there is everything) is never there." $" 81$

\footnotetext{
${ }_{77}^{77}$ Gilligan, In a Different Voice, p.19.

78 Time and the Other, p. 87.

${ }^{79}$ Gilligan, In a Different Voice, p. 8

80 Time and the Other, p. 86.

${ }^{81}$ idem, p. 88. An interesting parallel may be found in Nietzsche, Thus Spake Zarathustra,
} 
It may be Gilligan who deciphers the secret of which Levinas speaks:

“The elusive mystery of women's development lies in its recognition of the continuing importance of attachment in the human life cycle. Woman's place in man's life cycle is to protect this recognition while the development litany intones the celebration of separation, autonomy, individuation, and natural rights. The myth of Persephone speaks directly to the distortion in this view by reminding us that narcissism leads to death, that the fertility of the earth is in some mysterious way tied to the continuation of the mother-daughter relationship, and that the life cycle itself arises from alternation between the world of woman and that of men." 82

Should feminine moral reasoning, we may ask, be seen as a product of anatomical, biological difference, or of the existence of a feminine spirit, or is it in fact a product of social or psychoanalytic factors that shape society and mold the individual boy or girl within the society into one of the available patterns?

Feminine morality is described by Gilligan as a characteristic of the feminine, and it would seem that Levinas, too, is prepared to accept this moral description of responsibility, of concern, of empathy as feminine characteristics. Therefore he employs the terms of hosting, of dwelling, and of motherhood, but for Levinas these characteristics of morality are applied to both the feminine and the masculine.

While Gilligan describes feminine morality as related to the feminine character, which is different from the masculine, and thus feminine morality stems from something internal to women (a stand which drew sharp criticism from some quarters), for Levinas ethics can be described as founded upon feminine phenomena, but the ethical imperative does not have its source in a human character that includes responsibility, empathy, or dependence and relationship toward another person. For him, the ethical imperative is the opposite of the natural will, or the will of what exists to continue to do so and to provide itself with pleasure. 
That imperative stems from the disturbance of the face of Other, the interference of encounter with someone of the other sex, and even in the threat that comes from another person. It is not a positive predilection, about which one may say that it either is there or is not there. It is an imperative that imposes itself upon the natural and about which one may say that it is beyond the I, beyond the subject, and approaches it by one's being addressed by another subject, masculine or feminine. ${ }^{83}$

The Talmud employs the figure of Elijah to explain the significance of the feminine. ${ }^{84}$ Levinas writes that Elijah's image exemplifies the possibility of change that one person can accomplish. The Elijah of the Bible is a most masculine figure. He does not have a wife. He is zealous, even fanatic. But in the talmudic legend, it is nevertheless Elijah who offers instruction in the feminine. Furthermore, rabbinic literature portrays him as a soft, tender, comforting person.

Levinas himself advocated this kind of thinking, in his conversations with Philip Nemo:

"Perhaps $[\ldots]$ all these allusion to the ontological differences between the masculine and the feminine would appear less archaic if $[\ldots]$ they would signify that the participation in the masculine and in the feminine were the attribute of every human being. Could this be the meaning of the enigmatic verse of Genesis 1:27, "male and female created He them?",85

Similarly, in a conversation with Bracha Lichtenberg Etinger:

\footnotetext{
${ }^{82}$ Gilligan, In a Different Voice, p. 23.

${ }^{83}$ Tronto raises a principal argument about two ethical positions that confront each other, and she tries to go beyond the necessity of gender in creating alternative ethics: J. Tronto, Moral Boundaries: $A$ Political Argument for an Ethic of Care, New York andLondon 1994.

See also another ethical position that goes beyond Gilligan: M.U. Walker, "Moral Understanding: Alternative 'Epistemology' for a Feminist Ethics," Hypatia 4 (1989), pp. 15 - 28; N.J. Hirschmann, Rethinking Obligation: A Feminist Method for Political Theory, Ithaca 1992.

84 Judaism and the Feminine, pp. $32-33$

${ }^{85}$ Ethics and Infinity, pp. 68-69.
} 
"Before the face of the other I am already obligated [...] And then, there is the idea of the feminine, or of love, of love relationship with the woman [...] But it has this meaning in the face of any presence of the other, for every human being." 86

There are two interpretations possible here. The first is an androgyny that would explain the female and male aspects of each person. One can present this kind of thinking as a Jungian thought. This option may appear congruent with Levinas's position as described above, the duality that is previous to gender difference. This option, though, does not take the category of the feminine seriously.

The second option, far more significant, is that gender difference is fundamental for Levinas, although for the masculine the feminine has implications. The feminine demands that the individual internalize the female ethic. The feminine is no longer an abstract category but an ethical imperative.

Perhaps it is possible to see this insight in Levinas's interpretation of circumcision. Levinas suggest understanding circumcision as a form of castration, just as Freud did. ${ }^{87}$ Circumcision is regarded as an act of damage, a primary injury that precedes all the other injuries that will come in the future.

Levinas regards this primary injury as an opening toward others. ${ }^{88}$ The deep meaning of this damage is described by Levinas as damage done to the ego, as damage done specifically to

\footnotetext{
${ }^{86}$ Time Is the Breath of the Spirit, p. 21.

${ }^{87}$ Castration anxiety is discussed extensively in Freud's writings. See, in the context of the anxiety toward the father, S. Freud, An Outline of Psychoanalysis, trans.: J. Strachey, New York 1949, pp. 8899 ; O. M. Ozturk, "Ritual Circumcision and Castration Anxiety," Psychiatry 36 (1973), pp. 49-60. E. A. Lèvy-Valensi, Les voies et les pièges de la psychanalyse, Paris 1971.

${ }^{88}$ See J. Derrida, Shiboleth, Paris 1986,_. Derrida continues the description of the circumcision as an openess before the others.
} 
virility, in order that the person will be slightly feminine. It is not merely a mode of castration, but a choice of alternative modes of subjectivity: ${ }^{89}$

"It is linked with the conclusion of the covenant, with the considerable event in the heavenly Torah of a sociality between man and the transcendence, with sociality being accomplished as transcendence. This is a concept essential to Judaism: that the consent to a corporeal wound to be undergone - or to have one's newborn son undergo places us beyond all pious rhetoric and outside the pure "inner realm" in which ambiguity, amidst unverifiable "mysteries." "90

For Levinas, readiness to be injured creates the dimension of an "inner realm" of openess to the other. Circumcision makes the "inner realm" of the feminine possible for the masculine. The female movement of transcendence can be internalized by the masculine subject.

One important aspect of the circumcision ceremony is naming and being named. Abraham acquires his new name at the time of his circumcision. This bodily reduction of virility is a foundational event that reconstructs the Subject. For Levinas the circumcised man is now subordinate to the feminine: after Abraham's circumcision, God tells him, "In all that Sarah says to you, obey her voice" (Genesis 21:12).

Should we see in this phrase the full meaning of the feminine as an alternative Subjectivity?

"Is this new interdiction? A related side issue? Or, on the contrary, an essential problem for 'a time that overflows memories? Will the woman's condition for ever remain inseparable from the possessive that contains - or deforms - the second syllable of a word meaning, in the case of Abraham's wife, the sovereignty of a princess? The sovereignty of a princess or of a human person! But also the sovereignty of a woman, who in a masculine world, always runs the risk of being taken as a thing to be owned. The dramatic ambiguity of the feminine, which

\footnotetext{
89 "Contempt for the Torah as Idolatry," In the Time of the Nations, pp. 55-75.

90 "Contempt for Torah as Idolatry," p. 63.
} 
has won her only the folklore supremacy of the woman celebrated in a song, but already owned; sung, but a plaything - incapable of validation as humanity rising above the local setting to be a princess for all humanity. The dramatic ambiguity of the feminine that vanishes in the world of Abraham exceeding the past. Henceforth, dignity of the person that has regained her fullness and accedes to the highest vocations of the human. This ontological correction is announced by God precisely to the husband. Abraham will soon hear (Genesis 21:12): 'And in all that Sarah says to you, obey her voice.' In prophecy itself, a possible subordination of the male inspiration to the female." 91

As mentioned above, Levinas makes a connection between God and the womb. The idea of divinity as womb is one that makes it possible to describe God's infinite nature as an openness to different possibilities, an openness to a future time that will arrive by human agency. The womb as the possibility of containment, the ability of opening up to the other, is a distinctly feminine phenomenon:

"Rakhamim is the relation of the uterus to the other, whose gestation takes places within it. Rakhamim is maternity itself. God as merciful is God defined by maternity. A feminine element is stirred in the depth of this mercy. This maternal element in divine paternity is very remarkable." 92

The depiction of the feminine as inclusive finds expression in the Tabernacle and the Tent of Meeting - Ohel Moed. This was where God revealed Himself to Moses and to Israel, during the forty years of wandering. This tent is an open space for gathering and encounter $/{ }^{93}$ This special place makes the covenant possible. This tent is parallel to the womb, to the divine womb that represents God as an encompassing space.

91 "Beyond Memory", In The Time of the Nations, trans.: M. B. Smith, Bloomington - Indianapolis 1994, p. 86.

2 "Damages Due to Fire," p.183. 
We may thus say:

Levinas's stance toward the ethical imperative, as an imperative that comes from another person and precedes the subjective, is similar and parallel to the view of feminine morality proposed by Gilligan, which is founded upon responsibility and nearness.

Levinas's ethical position is not directed at women or men alone; it is directed at the individual as such.

Levinas's descriptions of the characteristics of the feminine and of feminine phenomena are close in meaning to his ethical imperative.

Levinas may be suspected, in describing the feminine, of applying characteristics of masculine thinking in order to capture the feminine phenomenon.

The ethical imperative is, at its base, described by the phenomenon of the external, by the face of the Other commanding "Thou shalt not murder." But Levinas describes another ethical imperative whose source is in an inward movement, the transcendent movement of the feminine.

93 "The Pact," Beyond the Verse, trans.: G. D. Mole, Bloomington - Indianapolis 1994, pp. 68-85, especially pp. 81-83. 